\title{
Social Media for Social Justice in Adult Education: A Critical Theoretical Framework
}

\author{
Erin J. Careless \\ Mount Saint Vincent University
}

\begin{abstract}
Social media as a communicative forum is relatively new, having been around for only ten years. However, this form of digital engagement has revolutionized the way many people interact, network, form relationships, learn, generate and share knowledge. As a noncentralized tool for communication, social media may provide space for critical discourse around issues of social justice, as discussion can be global in scope and is controlled by users themselves. This paper outlines a critical theoretical framework through which to explore the use of social media in adult education to foster such critical and social justice-themed discourse. Drawing upon five critical theorists and their work, this framework sets the stage for a future research project - one that is significant for this increasingly digital world in which we live.
\end{abstract}

\section{Introduction}

The purpose of this paper is to establish a theoretical framework through which to study the use of social media in adult education as a way to foster critical thinking and an awareness of social justice issues. While there is a body of research around the use of social media in varying educational (LeNoue, Hall \& Eighmy, 2011; Reich, Levinson \& Johnston, 2011), community (Lim, 2011; Joseph, 2012) and workplace settings (McKay \& Vilela, 2011; Pikalek, 2010) for networking and community engagement, there is little around the use of social media for critical thinking and social justice awareness. Research in this area has become increasingly important as social media and other digital technologies become further integrated in society.

The term "Internet" was first used in 1974, but by the year 2010 two billion people identified as Internet users (Robinson, 2011). The rapid pace of growth in digital technologies has dramatically altered the way much of the Earth's population work, socialize, generate and share knowledge. As part of this larger body of digital technology, social media is a tool which has revolutionized communication since its emergence approximately ten years ago. According to a report published by Moran, Seaman and Tinti-Kane (2011), "the term social media is a hazy one. And no wonder - for the first time, the world faces a medium that is by its very nature noncentralized, meaning that in both form and content, it is user created, user controlled, flexible, democratic, and both very transparent and very not so" (p.4, emphasis in original). As social media facilitates global discourse and is unbound by the policies of formal education, this digital medium is a potentially powerful tool for developing critical discourse and education for social justice.

Critical social theory, while broad and diverse in its perspectives, provides the framework for this research. Critical theorists typically believe that reality is socially constructed and reproduced by people; that their lives are shaped by social, cultural, economic, and political forces. By illuminating inequities and oppression in society, critical theorists challenge dominant ideologies. Historical critical theorist Karl Marx focused on a class analysis of inequity in society. As critical discourses have evolved over time, some began to challenge traditional frameworks that focused on class alone and the patriarchal, Eurocentric experience. In a revolutionary publication, Ellsworth (1989) identifies the traditional canon of critical theory as abstract and removed from the daily activities of critical educators, leaving issues of power, voice, and representation unchallenged and relations of oppression free to reproduce (Ellsworth, 1989). This and other foundational pieces opened up different approaches to critical thinking from multiple and diverse standpoints that addressed cultural, social, economic, and political factors.

In the introduction to their edited collection of feminist essays on the critical tradition, Luke and Gore (1992) talk about their realization that the traditional texts did not speak to them directly:

After years of uneasy readings of the fathers, our various responses to the discourse of critical pedagogy were not 'critical' choices, conscious moves in a moment of avant-garde leftist leaning toward a culturalist or continental 'theory' of the subject. Rather, our readings of critical pedagogy 
have been arrived at out of our positioning, location and identity as women in education: as women within a patriarchal system of knowledge, scholarship, and pedagogical relations. (p. 3)

The contemporary work of theorists such as Ng (1993), Mojab, (2005), Grace and Wells (2007), Clark (2006), and Guo (2006) stress the importance of a critical theory that explores the intersection of gender, race, sexual orientation, ability, and class as factors impacting the individual experience.

In this paper I draw upon the work of five critical theorists to develop a framework for research on social media for social justice. Although some of the theorists actually predate the advent of social media, their work is still relevant to this discussion. What follows is a brief overview of the historical and current contexts of adult education, and a discussion of the contributions made by five theorists as they relate to this research topic. The theorists are: Herbert Marcuse, bell hooks, Paulo Freire, Dorothy Smith, and Stephen Brookfield. I conclude with final thoughts on the potential for social media as a forum for critical discourse and social justice awareness.

\section{Historical Context}

Learning as a process is shaped by societal contexts, and the process of learning in turn influences the broader social context (Merriam, Caffarella \& Baumgartner, 2007). Traditionally, adult education has served both instrumental and social purposes. Skills training for employment, basic literacy programs, and homemaking classes reflect the historical instrumental needs of society. On the other hand, Martin and Shaw (1997) define the commitment to social purpose education as:

A recognition of adult education's role in contributing to the development of a just social order rather than as a means, primarily, of personal development and individual betterment; a concern to develop critical analysis which confronts issues of power, and seeks to connect local and specific struggles to the wider, social, economic and political context; an acknowledgement that educational practice - and, in particular, the role of the worker - must be consciously and systematically located within current policy developments. (p. 12)

Adult education for social purposes concerns working toward equality, citizenship and democratic participation.

In Canada following World War I, Father Jimmy Tompkins published Knowledge for the People (1921) where he discussed the longing of citizens to gain more knowledge and organized effort in their vocational callings (Welton, 2006). Education for the betterment of society is echoed in the work of another Canadian adult educator, Reverend Moses Coady, who believed that "the first step in the being of anything is the theoretic or the vision of possibilities of things that might be. Education, and in particular adult education, should enable people to get this vision of possibilities" (St.F.X \& Moses Coady, n.d.). Questioning the state of adult education as a "movement", Selman (2011) describes the historical development of education:

The vision was a liberal one, not a radical one. One factor that unites such initiatives as the Antigonish movement, Frontier College, Radio Farm Forum, Countrywomen of the World, and Citizens Forum is that they sought to improve opportunities for individuals within a system. They were not primarily about overturning the system. In this sense they were about equality and social justice, but the conceptions of equality and social justice were understood through a lens of optimism about progress, particularly in Canada, where it was thought that class structure was largely a thing of the past and that education about matters such as scientific agricultural techniques and international affairs would contribute to Canada's development. (p. 2)

We must bear in mind that Selman's (2011) article represents a Canadian perspective, and that in other parts of the world adult education sometimes served a political purpose with aims of inciting a social revolution, as we can see for example, in Freire's (1970) work, Pedagogy of the Oppressed.

While social purpose education was intended to help citizens live and participate in a democratic society, the Industrial Revolution of the late $19^{\text {th }}$ and early $20^{\text {th }}$ centuries fueled a focus on education for skills training and citizenship programs for immigrants (Merriam, Caffarella \& Baumgartner, 2007). Formal 
education has always had instrumental purposes, but socioeconomic changes in the modern, industrial society strengthened this connection significantly. The Industrial Revolution signified the beginning of a commodity exchange economy, a dynamic that began to determine all human relationships (Brookfield, 2005). In this economic system, goods produced for exchange are given an innate value reflective of its predicted market worth. The objects become, what Marx refers to as, fetishized: "This fetishism of commodities has its origin . .. in the peculiar social character of the labor that produces them" (Marx, 1867/2009, p. 39). It is not only objects that become fetishized; our intellectual labor also becomes something apparently existing outside of us and that we can exchange for money (Brookfield, 2005). This is where we see the connection between education and the market, skills and knowledge for economic exchange.

\section{Current Context}

In contemporary Western society, the adult education sector is increasingly shaped by the dominant capitalist social system that focuses on values of production, competition, consumerism, and acquiring skills and credentials for participation in the global marketplace. The ideology of this economic system whereby the state and market are intricately and intimately entwined dictates the actions and behaviors of many citizens, at times marginalizing those who engage in ideology critique: "In this discourse, concerns about adult learning to promote democracy, active citizenship, and personal development are noticeably absent" (Elfert \& Rubenson, 2013, p.245). Critical educators note that education programs and policies often reflect the needs of this dominant capitalist system, where learners are seen as consumers of knowledge and credentials to be used in exchange for employment and wages in the workforce: "As global capitalism has gained momentum, a pervasive worldview has developed so that the logic of the marketplace is the logic of the world. This can be seen increasingly in adult and higher education contexts" (Gouthro, 2006, p. 11). The instrumentalization and bureaucratization of higher and adult education signifies a major shift from the historical purposes of education: "Adult learning seems to have become a vehicle for solidifying a socioeconomic structure that limits access and opportunity, contrary to the stated goal of equal access to education in our society" (Merriam, Caffarella \& Baumgartner, 2007, p. 3). While instrumental purposes are not entirely negative skills training and literacy programs are important for active participation in society - a balance of instrumental needs and social justice philosophy can shape a productive and democratic society.

Critical theorists with diverse perspectives and interests challenge this emphasis on market values in education. For example: Grace (2012) explores the growing divide between historical, social education and contemporary professionalized practice; Olssen (2006) discusses the impact of neoliberalism in education and the critical role education plays in learning for democracy to challenge this; Plumb (1999) looks at the impact of globalization on social and cultural processes of adult education, focusing on the modernist notions of space and time; Gouthro (2002) discusses the suppression of justice, equity, and critical thinking in education systems that are guided by marketplace values; and Taber (2010) explores the ruling relations of society and how we can begin to challenge them. These theorists share a common concern with power relations and how educational discourse is shaped by capitalist values in contemporary society.

Capitalism is no longer a strictly economic system, but is rather a cultural system that increasingly governs human life in Western society. Critical theory and education are important for keeping the bounds of such a pervasive system in check and to explore alternatives for social justice purposes:

Social justice education is a 'praxis' that includes a theoretical account of oppression and privilege, as well as practical strategies for changing social institutions. Schools are primary sites for this critical transformation since they reproduce inequality. Educating students to overcome internalized forms of oppression - such as racism, sexism, classism and homophobia, offering them a framework for understanding the external structures that are the source of these different oppressions, and empowering students to become agents of change, are all important goals of social justice education. (Kohli, 2005, p. 100) 
Where praxis refers to informed action, this quote emphasizes the unity of theory and practice for social justice education. I now turn to a discussion of five critical theorists and their work as it informs this research topic.

\section{Herbert Marcuse}

One of the founders of the Frankfurt School of critical theory in Germany, Marcuse has written extensively on the totalitarian attributes of industrial, capitalist society. Marcuse provides a critical interpretation of Hegelian-Marxist social theory, incorporating the work of Heidegger's phenomenology. In his popular book, One Dimensional Man (1964), Marcuse states that raising the standard of living for many in the traditional "working" class and generating consumer-driven "false needs" that perpetuate systems of production, allows the established society to maintain a level of social control over others. Known for his support of radical student movements in the 1960s, Marcuse makes important contributions to critical theory and education in the $21^{\text {st }}$ century.

\section{Learning outside the institution}

Marcuse was deeply interested in restructuring formal education for critical awareness and social change, and emphasized learning outside of educational institutions. In a speech made at the University of California, Berkeley, in 1975, Marcuse stated the importance of education for social emancipation:

It is true that we cannot change the goals of education without changing the society which sets these goals. But it is also true that we cannot wait for the revolution in order to become human beings, to eradicate sexism and racism in ourselves, to learn solidarity with the victims, to free ourselves from the cynicism and hypocrisy of the Established morality. In other words, the radical consciousness, and the vital need for radical change must emerge within the existing society and its institutions - there is no without! (Marcuse, 2009, p. 1)

Marcuse believed authentic education to be political and that both educators and the educated hold the responsibility for using their knowledge for the liberation and emancipation of others in society. In Counterrevolution and Revolt (1972), Marcuse states: "Those who are educated have a commitment to use their knowledge to help men and women realize and enjoy their truly human capabilities. All authentic education is political education, and in a class society, political education is unthinkable without leadership, educated and tested in the theory and practice of radical opposition" (Marcuse, 1972, p. 47). The connection between education and broader issues of society is often narrowed in contemporary adult education contexts to focus on professionalization and market values. Marcuse's insistence that this link be strengthened by connecting education to the greater society invokes the notion of critical, global discourse (Kellner, Lewis, Pierce, \& Cho, 2009). Digital technologies allow critical discourse to reach a broader audience, perhaps increasing the potential for greater social change.

\section{Achieving true democracy}

Marcuse felt that the purpose of education was to develop the knowledge necessary to enhance and protect our lives as human beings in society (Marcuse, 1968). His notion of one-dimensionality refers to individuals conforming to dominant ideological thoughts and actions; the absence of critical, or "negative" thinking to challenge oppression. Marcuse theorizes that education associated with this one-dimensional society is concerned with values of market and military logic, but is often presented under the guise of democratic education:

Democracy is a form of government and society which is supposed to institutionalize the actual freedom and equality of man as man,[sic] and that means, not only 'before the law,' but the abolition of domination and exploitation. In this sense, democracy is only to be created, and if its established form militates against the radical changes which would lead to such democracy, we must not be afraid of such changes. (Marcuse, 1968, p. 6) 
Dominant ideologies are maintained in the one-dimensional society by controlling potential sources of opposition - music, the arts, literature, and education (Reitz, 2009). This democratic unfreedom of thought and expression maintains a level of social control. Through repressive desublimination, where small measures of freedom or voices of critique are allowed to be heard, Marcuse believed that the established society convinces citizens that they live in a truly democratic society (van Heertum, 2006). Developing critical discourse and social action whether face-to-face or through the use of technology, may enable citizens to identify these oppressive tactics and incite change.

\section{Ability to envision alternatives in society}

Marcuse believed that social transformation was about more than critical consciousness and ideology critique, he also focused on developing a new way to view the world. Marcuse termed this the "Great Refusal" and focused on the power of marginalized individuals who typically resist conforming to dominant ideology:

Now, however, this threatening homogeneity has been loosening up, and an alternative is beginning to break into the repressive continuum. This alternative is not so much a different road to socialism as an emergence of different goals and values, different aspirations in the men and women who resist and deny the massive exploitative power of corporate capitalism even its most comfortable and liberal realizations. The Great Refusal takes a variety of forms. (Marcuse, 1969, p. vii)

In developing this alternative view, Marcuse emphasized a liberatory aesthetic education focused on arts education, sensual education, a return to nature, and pedagogical practice free of patriarchy and aggressive systems of reason (van Heertum, 2006). By envisioning alternatives to systems of technical rationality and bureaucratic rule, individuals may create a society concerned with "protecting and enhancing life, human freedom, which meant, and still means, social, political transcendence beyond the established culture" (Marcuse, 1968, p.3, emphasis in original). In an introduction to Marcuse's work, Kellner (1991) states that the Great Refusal continues to be practiced by groups on the margins; individuals who refuse to conform to systemic domination and oppression: "Marcuse should be widely read and studied again to help nourish a renewal of critical thinking and radical politics. For social domination continues to be a block to human freedom and happiness, and liberation continue to be a hope for those who refuse to join the contemporary celebration of militarism, the forces of conservatism, and unrestrained capitalism" (Kellner, 1991, p.xxxix). The vision of a just and equitable society motivates collective action. The recent Idle No More First Nations movement, a grassroots organization concerned with the protection of First Nations land, issues of treaty and sovereignty, was coordinated using Twitter, a form of social media. This medium allowed individuals and groups across Canada to coordinate planned demonstrations and draw international attention to their concerns for change. As quoted above, the Great Refusal takes many forms.

\section{Connection to social media for social justice}

The work of Herbert Marcuse remains significant for an analysis of today's technological society. While he analyzed the impact of technological development in society, Marcuse was not against technology; rather, he was concerned with its use for oppressive purposes. Although there is the potential for social media to be coopted by the dominant ruling relations in society, there is also the potential to be used in developing critical discourse. Social media as a digital communicative forum is controlled by users themselves; therefore, this is a space where citizens can discuss issues of democracy, social justice, and freedom in society. Because of the nature of social media, information is less likely to be offered in a top-down style and more likely to be generated, discussed, and challenged in a social context, not necessarily confined to formal educational settings. Marcuse insisted that people develop critical capacities in order to challenge oppression and inequality in society. In a global world, a global communication tool such as social media may play a key role in this critical awareness.

\section{bell hooks}


bell hooks is an American critical feminist and cultural critic whose prolific publications began at age nineteen. A significant theme in the work of bell hooks is that discrimination does not fall into separate categories, but rather is a combined force she terms "imperialist white-supremacist patriarchal capitalism". Therefore, one cannot examine sexism without also considering racism and class discrimination. hooks writes using narrative and intends for her books to be accessible to a diverse audience, opposing academic elitism and questioning power relationships in teaching and learning contexts. Her engaged pedagogy refers to holistic, critical educational practices that enforce the well-being of teachers and learners and challenges education as a site for indoctrination of dominant beliefs. Power is in literacy, freedom, education, and social justice.

\section{Voices from the margins}

hooks (2003) discusses the principles of exclusion that educational institutions have been built upon, and contemporary progressive educators who have begun to challenge the way "institutionalized systems of domination (race, sex, nationalist imperialism) have, since the origin of public education, used schooling to reinforce dominator values" (p. 1). In critical theoretical fashion, once the conservative foundations shaping formal education begin to be exposed, a space of critical and emancipatory potential emerges. Progressive educators focus on plural voices and diverse experiences as ways of knowing, in place of the media-driven capitalist, patriarchal values imposed by the dominant culture. Where diverse voices have historically been silenced in various learning contexts, democratic educators bring multiple ways of knowing to light through critical conversation and pluralism. According to hooks (2003), "pluralism is a commitment to communicate with and relate to the larger world - with a very different neighbor, or a distant community. Many educators embrace the notion of diversity while resisting pluralism or any other thinking that suggests that they should no longer uphold dominator culture" (p. 47). hooks promotes engaged pedagogy as a holistic and critical interpretation of pedagogy and a way for contemporary democratic educators to challenge dominant ideology. It is a way of valuing the voices and lived experiences of marginalized individuals (Berry, 2010).

\section{Consciousness-raising}

For meaningful critical thinking around social justice issues, learning and education must move from the "safe" place of lecture and hierarchical curriculum-based information to a place of resistance and critical engagement (Berry, 2010). hooks (2000) emphasizes the "importance of learning about patriarchy as a system of domination, how it became institutionalized and how it is perpetuated and maintained" (p. 7) as part of feminist consciousness-raising. Believing that these capitalist and patriarchal values are learned through the media amongst other sources, hooks (2000) believes that the first step to liberation is coming to an awareness of systems of domination. The term "consciousness-raising" is intimately linked to the feminist movement in the 1970s (very influential for hooks and her work) and discourse around valuing women's lives and experiences: "For many feminists and other social critics, consciousness-raising is central to the process of creating a critical awareness of our culture" (Sowards \& Renegar, 2004, p. 535). As an accessible and global communication medium constructed by users, social media is a forum in which these critical discussions can take place. Of course such discourse will not occur independently of engaged users, but this platform is a non-hierarchical tool for global discussion.

\section{Learning to change the world}

Society is changing at a pace more rapid than ever before, and perspectives on learning have felt the impact: "Today, it is no exaggeration to state that the driving force behind the massive implementation of the discourse of lifelong learning is no longer active citizenship, social inclusion or personal fulfillment, as proclaimed in the official rhetoric. The focus now is work-related and lifelong learning is primarily motivated by the scale of the breathtaking pace of current economic and social change" (Uggla, 2007, p. 213). With these changes, education and learning become de-politicized and individualized and people can be more concerned with their own success as opposed to fostering a democratic society that supports others. Where 
consciousness-raising is the first step to liberation, according to hooks (2000), the next step is political and radical action for change:

We need mass-based political movements calling citizens of this nation to uphold democracy and the rights of everyone to be educated, and to work on behalf of ending domination in all its forms - to work for justice, changing our educational system so that schooling is not the site where students are indoctrinated to support imperialist white-supremacist capitalist patriarchy or any ideology, but rather where they learn to open their minds, to engage in rigorous study and to think critically. (hooks, 2003, p. xiii)

These changes must take place not just in formal education settings, but in informal and nonformal learning contexts, in society as a whole. Unbound by educational curriculum and already a popular tool for mass-based movements, social media can help to facilitate this critical change.

\section{Connection to social media for social justice}

Through media and digital technologies we can "un-learn" dominant ideologies that persist today. These tools are only growing in use and adaptability, so we must find a way to incorporate digital communication forums into critical, political learning for social justice. bell hooks, while wary of the power of mass media, acknowledges its potential for change: "Whereas bell hooks writes widely and ranges across a number of disciplinary boundaries, it is no surprise that she would focus on the mass media as both a site of critique and an area to teach or formulate a resistant or revolutionary practice" (Valdivia, 2002, p. 439). Through informal and nonformal learning contexts, individuals who may not have access to formal education can participate in critical discussions around social justice issues using these digital platforms.

\section{Paulo Freire}

Brazilian educator and philosopher Paulo Freire is known for his contributions to the field of critical pedagogy. His work, based in part on Marxist theory and phenomenology, centered around liberatory pedagogical practice for those on the margins of society. Freire believed that the oppressed must first come to awareness of their situation in life before being a part of their liberation, and an essential part of this process is developing literacy skills. Freire put this notion to the test in the early 1960s when hundreds of rural farm workers were taught basic literacy skills. Freire was imprisoned for a short time before publishing his groundbreaking texts on critical pedagogy and liberation. Action as informed by certain values, or praxis, is a central theme in Freire's work, as is the development of critical consciousness for social transformation.

\section{Authentic dialogue}

Dialogue for Freire is an essential element of both liberatory pedagogy and social change, and is important to the discussion of social media as a communicative forum. As a social practice, dialogue reflects Freire's (1970) belief that the main objective for revolutionary educators is to transform reality with others: "Dialogue is a moment where humans meet to reflect on their reality as they make and remake it" (Freire \& Shor, 1987, p.13). Through dialogue, citizens develop a critical approach to remaking the world and challenging the dominant power structures. It is important to distinguish that Freire talks about authentic dialogue which is "never an end in itself but a means to develop a better comprehension about the object of knowledge. Otherwise, one could end up with dialogue as conversation where individual lived experiences are given primacy" (Macedo, 2009, p.18) over a critical engagement with both lived experiences and theory. It is a delicate balance. In contemporary society, social media may provide a digital forum to foster authentic dialogue on a global scale.

\section{Practice of freedom}

Freire believed liberatory education to be a practice of freedom against oppression, in contrast to education that enforces social control and capitalist modes of production: "Education either functions as an instrument 
which is used to facilitate integration of the younger generation into the logic of the present system and bring about conformity or it becomes the practice of freedom, the means by which men and women deal critically and creatively with reality and discover how to participate in the transformation of their world" (Freire, 1970, p.64). Individuals may be intimidated by the notion of challenging dominant ideological forces in society that dictate actions and behaviors, but "freedom is acquired by conquest, not by gift. It must be pursued constantly and responsibly. Freedom is not an ideal located outside of man; nor is it an idea which becomes myth. It is rather the indispensable condition for the quest for human completion" (Freire, 1970, p.47). In contemporary society, dominant ideological practices are often maintained using tools and instruments that are common in society, for example, through education, mass media, and popular culture: "More and more, the oppressors are using science and technology as unquestionably powerful instruments for their purpose: the maintenance of the oppressive order through manipulation and repression" (Freire, 1970, p.60). When social media is used as a communicative tool for critical, global discourse, citizens may control the conversation, but it is possible for this media to be coopted to enforce the dominant ideology. Educational change must happen in conjunction with changes in political and social structures for them to be everlasting (McLaren, 1999).

\section{Literacy as knowing the world}

Freire believed strongly that reading context and text were akin to reading the world and the word, and the deconstruction of language is a tool to cultivate either dominance or freedom. The practice of literacy is a powerful revolutionary tool, and understanding how our lives are mediated by language and text in its various forms is essential for enacting change. Critical literacy is important to Freire's theory as a process of understanding how "texts and discourses can be manipulated to represent and indeed, alter the world" (Luke, 2012, p.9). "Naming" the world through literacy practices enables individuals to come to critical awareness of their place in the world. Therefore, to "name" the world is to identify dominant ideologies shaping everyday actions and behaviours - the precursor to action for social justice and equality (Freire, 1970). With advancements in technology and the impact of globalization, ideological practices may be more pervasive and therefore harder to identify in contemporary society. This makes critical literacy an even more important skill to develop.

\section{Connection to social media for social justice}

Freire's notion of liberatory pedagogy involves dialogue as a measure of respect for others; as working together to enact social change. Social media provides a forum for dialogue with others and the potential for social change. As a medium unbound by pedagogical policy, new media have created dynamic and enabling conditions for social movements and politics (Luke, 2012). There is the possibility of using literacies and dialogue to change relations of power - both in everyday social relations and in broader sociopolitical contexts - through emancipatory practices. Social media presents a way for individuals to participate in critical discourse for liberation.

\section{Dorothy Smith}

Dorothy Smith, a British sociologist, has lived in Canada for most of her influential academic career. Smith founded institutional ethnography, a methodological framework based in the social that begins where people are in their lives - with the individual standpoint. Having spent much of her adult life working within the bounds of a male-dominated field of sociological research, Smith began to question the assumption that the voices missing from theoretical discourse (those of women and other marginalized groups) were not worthy of being heard. Heavily influenced by changes brought on through the Women's Movement and her experiences as a single mother, Smith realized that her children and life at home were not present in the operations of the academic institution which represented her work sphere. Thus began Smith's quest for a sociology for women which later became a sociology for people; one that begins with the experiences of the individual. As a critical feminist who references Marxist theory and phenomenology, Smith's work contributes an important discussion on how gender relations shape the experiences of individuals in society. 


\section{Textually-mediated ruling relations}

Smith's methodological framework, Institutional Ethnography, focuses on studying the social relations that guide people's everyday lives through the interpretation of text. Rather than starting with the broad context of theory, Smith proposes starting within individual bodily experience and looking selectively outward to explore the translocal influence of ruling relations: "Institutional ethnography is committed to discovering beyond any one individual's experience including the researcher's own and putting into words... what she or he discovers about how people's activities are coordinated" (Smith, 2006, p.1). Ruling relations generally rely on text-based forms of knowledge and practice as central to organization of contemporary society: "A ruling class is the basis of an active process of organization, producing ideologies that serve to organize the class itself and its work of ruling, as well as to order and legitimize its domination. Ideologies take for granted the conditions of ruling-class experience" (Smith, 1987, p.57). DeVault and McCoy (2006) describe texts in terms of Institutional Ethnography as: "some kind of document or representation that has a relatively fixed and replicable character, for it is that aspect of texts - that they can be stored, transferred, copied, produced in bulk, and distributed widely... that allows them to play a standardizing and mediating role" (p.34). Smith believes that our daily actions and behaviors are regulated by the growing texts and ruling relations that seem removed from day-to-day life. Being aware of how our lives are linked to these ruling relations can help reduce our level of frustration in society when things seem to happen out of our control (Campbell, 2006). The knowledge that our actions are governed in this way is the first step to taking critical action to enact social change.

\section{Starting with the individual experience}

As opposed to traditional "top-down" frameworks in sociology that begin with theory, Smith's Institutional Ethnography begins with the individual experience and then looks outward into the relations and institutions that govern everyday actions:

It is this essential return to the experience we ourselves have directly in our everyday worlds that has been the distinctive mode of working in the women's movement - the repudiation of the professional, the expert, the already authoritative tones of the discipline; the science, the formal tradition, and the return to the seriously engaged and very difficult enterprise of discovering how to begin from ourselves. (Smith, 1987, p. 58)

Experience is an important way to reveal the relations of ruling that shape individual experiences (DeVault \& McCoy, 2006). Individuals then reproduce regulatory texts in their daily lives without consciously doing so because texts are so ingrained in daily life. Smith touches on this reproduction of social relation in her book co-authored with Allison Griffith, Mothering for Schooling (2005). They believe that that the formal education system reproduces class distinctions by appropriating the supplementary work of mothers in the home. Mothers often rely on texts of the mothering discourse to guide their behavior and in this example, mothers provide extra support for their school aged children, thereby reproducing the cycle of mothering discourse around school support: "We discovered a discourse that we have come to call the discourse of mothering that mobilizes the work, care, and worries of mothers in relation to their children's schooling. By discourse we mean a systematically developed knowledge, morality, and set of values that are expressed in definite ways of writing and speaking" (Griffith \& Smith, 2005, p.33). By starting with the individual, institutional ethnographers can explore the organization of everyday behaviors. Rather than supporting dominant practices that begin with theory, Institutional Ethnography implies an exploration of ruling relations and how they are acted out through the behavior of the individual.

\section{Gender relations}

Smith's critical feminist perspective provides an analysis of how gender relations impact individual experiences within social relations. "Developing a sociology for women/people started with the idea of beginning in the standpoint of a housewife and mother in the actualities of her everyday world and anchoring 
an investigation of the social in the concrete actualities of the everyday and everyday doings" (Syracuse Website). Smith's work in the social organization of knowledge gained influence by being situated within a community of radical feminist scholars (DeVault \& McCoy, 2006). Institutional Ethnography with critical and liberatory goals of understanding social relations and processes that lead to oppression is intimately linked with feminist research. In her book, Mothering for Schooling (2005), Smith states that "an engine of inequality has been described, interlocking the unpaid labor of (middle-class) women in the home and the local practices of schools" (Griffith \& Smith, 2005, p.127). Smith also notes that the exclusion of women from dominant discourse is not the only one, ruling relations exclude the working class, ethnic and racial minorities, and homosexual men and women (Smith, 1987). Critical discourse challenging this exclusion is necessary, and may be supported by the use of digital communication tools.

\section{Connection to social media for social justice}

Smith's work makes a valuable contribution to the discussion of social media for social justice, as her research focuses on ruling relations and how they govern everyday actions and behaviors. Social media as a usergenerated communicative forum can be used to challenge these relations in a noncentralized format. Smith's critical feminist work looks at the historical absence of women's voices from theory. While the use of social media may or may not vary according to gender, having a highly accessible platform for critical discourse provides the opportunity for historically silenced voices to be heard. In Smith's own life as a single mother and an academic, she talks of the feeling of isolation, that these two elements of her life were incompatible. As a way to build connections and engage in discourse with others in similar situations, social media may facilitate consciousness-raising and agency for creating change.

\section{Stephen Brookfield}

Stephen Brookfield is a critical theorist, educator, and author who has published extensively in adult learning, teaching, critical thinking and theory. His work provides a theoretical framework for critical thinking and focuses on its implementation in formal classroom settings - for both learners and educators. Brookfield provides concrete activities and suggestions to incorporate critical thinking into one's pedagogical practice, and believes in the power of dialogue and socially constructed knowledge. Like hooks and Smith, Brookfield is a contemporary theorist who approaches the notion of critical pedagogy within the current sociological context.

\section{Dialogue and the social construction of knowledge}

In his work on teaching learners to think critically, Brookfield places significant emphasis on dialogue and the social construction of knowledge. He discusses participatory discourse as a way to achieve democracy, and references his own teaching practice and how it has changed over the years. At one time viewing circle discussion groups as a non-political process of creativity and improvisation, Brookfield (2005) acknowledges the potential to reproduce social inequities: "Too often what is justified as a laissez-faire approach meant to demonstrate the teacher's refusal to dominate conversation actually serves to bolster wider social inequities and have been imported into the group. The people who talk the loudest and longest inside the classroom are often those whose social locations mean their voices get the most attention in the world outside" (p. 355). This is an important consideration and draws attention to pre-existing tensions and rules governing conversation. The notion of knowledge as socially constructed also implies an interest and participation on the part of individuals to work together to "create" knowledge. However, Brookfield (2005) discusses the common issue of resistance to engaging in critical thinking and discourse. He identifies:

Five elements in critical theory [that] seem to present particular problems for them in terms of provoking resistance: the emphasis on Marx, the critique of capitalism the theory entails, the questioning of democracy (particularly the identification of the tyranny of the majority), the difficult language used by critical theorists, and the radical pessimism induced by constantly reading analyses that emphasize the power of dominant ideology and the way it effectively forestalls any real challenge to the system. (p. 358) 
These tensions are often closely linked with learners' personal lives or to trigger preconceived ideas about the critical process. Emphasizing the self-critical nature of critical theory itself is a way to respond to student resistance (Brookfield, 2005). Another approach to teaching critical theory that may invite resistance from learners is translating theory to such a degree that the key ideas are distorted. Grace (2006) states that "Brookfield casts such oversimplification as a neutering of the work and a diminishment of the voices of powerful critical theorists" (p.129). Engaging in truly critical dialogue, through any medium, is important to understanding different perspectives and developing alternative views of society.

\section{Power and politics}

To Brookfield, education imbedded in critical theory is education with a political and social purpose: "Critical theorists intend that their analyses and concepts will help people create social and economic forms distinguished by a greater degree of democratic socialism (Brookfield, 2005, p.350). In fact, he believes that the major objective to teaching people to think critically is to empower them to create a truly democratic system: "Critical thinking framed by critical theory is not just a cognitive process. It is inevitably bound up with realizing and emphasizing common interests, rejecting the privatized, competitive ethic of capitalism and preventing the emergence of inherited privilege" (Brookfield, 2005, p351). Critical education is not neutral, it is political. Central to this critical tradition in education is the ability to exercise conceptual thought: "Freedom, fairness, equity, liberation, the ethical use of power - all these 'big' ideas are central to the critical tradition" (Brookfield, 2005, p.353). Learning to recognize how power is acted out in our lives; how it is used, abused, and how we can exercise it, it an essential task of critical learning theory for Brookfield (Merriam, Caffarella \& Baumgartner, 2007). There are so many way to approach critical theory and its purpose in education given the diversity that makes society so rich. However, what remains constant in critical theory for educators is the potential for political and social change, and awareness that critical self-reflection is a must.

\section{Connection to social media for social justice}

Brookfield's work is relevant to social media for social justice in terms of dialogue and the social construction of knowledge for social change. Critical discourse can take place in person, but through social media can occur on a global scale. Using these digital tools, power is in the hands of individual users and their construction of knowledge. Brookfield himself identifies challenges in facilitating education that is critical, where power is shared between educators and learners. No matter the teaching style, the very structure of formal education implies a power imbalance - someone has to grade the papers. Social media as a noncentralized tool for communication and learning that is not formally evaluated can allow users to engage in discourse with others without that immediate power differential. Someone may be enrolled in a course where they do not feel a connection with anyone else in the room, but through digital technology can communicate with peers in various locales around the world. Brookfield's critical thinking for education aims to empower individuals with the skills to identify and challenge inequitable systems in society, and a potential forum for these discussions is online.

\section{Social Media for Social Justice}

Originally created for networking and generating personal profiles (Kaplan \& Haenlein, 2010), people use social media in ways that "parallel but depart from or extend earlier media for communication, such as letter writing, telephone... and so forth" (Markham, 2011, p.114). Although social media is still an emerging tool for communication, it is important to encourage its use for critical, revolutionary purposes in education: "One of the most important potential roles for electronic communication... is enhancing public discourse - a form of discourse that joins strangers and enables large collectivities to make informed choices about their institutions and their future" (Calhoun, 2004, p.48). As a compliment to social revolutions such as protests, marches, community meetings, and student movements, social media may be a space for critical, revolutionary discourse to take place.

In contrast to websites that allow users to access information already generated, Web 2.0 refers to websites that have moved beyond this static one-way access, allowing users to collaboratively generate 
knowledge and participate in discussions using social media forums. Janks (2012) states that new media advances in Web 2.0 technology have been used to disseminate counter-discourses, question and destabilize power. Not only is content user-generated in these technological spheres, but conversations can occur at any time and in any location (Samuels, 2011), transcending the space and time limitations of face-to-face conversation. "Social media" as a communicative forum is not "out there" waiting to be accessed by individuals; rather, its construction, reconstruction, and deconstruction depend on those engaged in digital discourse.

There are, of course, issues to consider when discussing the use of social media to facilitate critical discourse and awareness of social justice issues. In the short time social media has been influential to many in society, it has become inextricably linked with the marketplace through advertising and strategic placement of information. Whether it is suggested "Likes" on a Facebook news feed or "trending" topics on Twitter, social media is certainly shaped by the consumerism of the Western world. Such strong ties to the capitalist value system may impact on the criticality of social media discourse. Connected with this issue is the notion of surveillance. Advances in technology bring both more and less freedom as digital interactions and behaviors are easily monitored by others, begging the question of power and ruling relations. Another consideration is access - while millions and millions of people use social media, there are many more who do not have access to the technology and those are important voices not heard.

Despite the challenges, social media is still a vastly influential tool in society - one that warrants more critical research and exploration. Critical social theory is an appropriate theoretical framework through which to explore the use of social media as a potential forum for social justice and liberatory pedagogy in adult education. In a very short time, social media has virtually changed the way many people communicate, generate and access information, and engage in civil society. In a recent edition of The Globe and Mail, a national newspaper, an editorial piece focused on this very idea: "Social media... will continue to evolve, but it is here to stay... We owe it to ourselves to consider the ways in which it is changing the nature of our public discourse and, through those changes, the manner in which we govern ourselves. Our democracy is being changed for the better, 140 characters at a time" (Boyko, 2013, p. A11).

\section{References}

Boyko, J. (2013, April 22). Changing democracy, 140 characters at a time. The Globe and Mail, pp. A11.

Brookfield, S. (2005). The power of critical theory: Liberating adult learning and teaching. San Francisco, CA: Jossey-Bass. Brookfield, S. (2012). Teaching for critical thinking: Tools and techniques to help students question their assumptions. San Francisco, CA: Jossey-Bass.

Calhoun, C. (2004). Information technology and the international public sphere. In D. Schuler \& P. Day (Eds.), Shaping the network society: The new role of society in cyberspace (pp.229-252). Cambridge, MA: MIT Press.

Campbell, M. (2006). Institutional ethnography and experience as data. In D. Smith (Ed.), Instrumental ethnography as practice (pp. 91-107). Lanham, Maryland: Rowman \& Littlefield.

Clark, M. (2006). Adult education and disability studies, an interdisciplinary relationship: Research implications for adult education. Adult Education Quarterly, 56(4), 308-322.

DeVault, M. \& McCoy, L. (2006). Institutional ethnography: Using interviews to investigate ruling relations. In D. Smith (Ed.), Institutional ethnography as practice (pp.15-44). Lanham, Maryland: Rowman \& Littlefield.

Ellsworth, E. (1989). Why doesn't this feel empowering? Working through the repressive myths of critical pedagogy. Harvard Educational Review, 59(3), 297-324.

Fenwick, T., Nesbit, T., \& Spencer, B. (Eds). (2006). Contexts of adult education: Canadian perspectives. Toronto, ON: Thompson Educational Publishing.

Freire, P. \& Shor, I. (1987). What is the "dialogical method" of teaching? Journal of Education, 169(3), 11-31.

Freire, P. (1992). Pedagogy of hope. New York: Continuum.

Freire, P. (2009). Pedagogy of the oppressed. New York: Continuum. (Original publication date 1970).

Giroux, H. (2004). Cultural studies and the politics of public pedagogy: Making the political more pedagogical. Parallax, 10(2), 73-89.

Giroux, H. (2005). Border crossings: Cultural workers and the politics of education. New York: Routledge.

Giroux, H. (2011). The crisis of public values in the age of the New Media. Critical Studies in Media Communications, 28(1), 829.

Gouthro, P. (2006). Reason, communicative learning, and civil society: The use of Habermasian theory in adult education. The Journal of Educational Thought, 40(1), 5-22. 
Grace, A. \& Wells, K. (2007). Using Freirean pedagogy of just ire to inform critical social learning of arts-informed community education for sexual minorities. Adult Education Quarterly, 57(2), 95-114.

Grace, A. (2006). Critical adult education: Engaging the social in theory and practice. In T. Fenwick, T. Nesbit, \& B. Spencer (Eds.), Contexts of adult education: Canadian perspectives (pp.128-139). Toronto, ON: Thompson.

Grace, A. (2012). The decline of social education and the rise of instrumentalism in North American adult education (19471970). Studies in the Education of Adults, 44(2), 225-244.

Griffith, A. \& Smith, D. (2005). Mothering for schooling. New York: RoutledgeFalmer.

Guo, S. (2006). Adult education for social change: The role of a grassroots organization in Canada. Convergence, 39(4), 107-122.

Hare, W. \& Portelli, J. (Eds). (2005). Key questions for educators. Halifax, NS: Edphil.

hooks, b. (2000). Feminism is for everybody: Passionate politics. Cambridge, MA: South End Press.

hooks, b. (2003). Teaching community: A pedagogy of hope. New York, NY: Routledge.

Janks, H. (2012). The importance of critical literacy. English Teaching: Practice and Critique, 11(1), 150-163.

Joseph, S. (2012). Social media, political change, and human rights. Boston College International and Comparative Law Review, $35(1), 145-188$.

Kaplan, A. \& Haenlein, M. (2010). Users of the world, unite! The challenges and opportunities of social media. Business Horizons, 53(1), 59-68.

Kellner, D. (1991). Introduction to the second edition. In H. Marcuse (1964/1991), One-dimensional man (pp.xi-xxxix). Boston: Beacon Press.

Kellner, D. (2001). Critical pedagogy, cultural studies, and radical democracy at the turn of the millennium: Reflections on the work of Henry Giroux. Critical Studies - Critical Methodologies, 1(2), 220-239.

Kellner, D., Lewis, T., Pierce, C., \& Cho, K. (2009). Marcuse's challenge to education. Lanham, Maryland: Rowman \& Littlefield.

Kohli, W. (2005). What is social justice education? In W. Hare \& J. Portelli (Eds.), Key questions for educators (pp.98-101). Halifax, NS: Edphil.

LeNoue, M., Hall, T., \& Eighmy, M. (2011). Adult education and the social media revolution. Adult Learning, 22(2), 4-12.

Lim, M. (2012). Clicks, cabs, and coffee houses: Social media and oppositional movements in Egypt, 2004-2011. Journal of Communication, 62, 231-248.

Luke, A. (2012). Critical literacy: Foundational notes. Theory into Practice, 51(4), 4-11.

Luke, C. \& Gore, J. (1992). (Eds.). Feminisms and critical pedagogy. New York: Routledge.

Macedo, D. (2009). Introduction to the anniversary edition. In P. Freire (1970/2009). Pedagogy of the oppressed (pp.11-28). New York: Continuum.

Marcuse, H. (1964). One-dimensional man: Studies in the ideology of advanced industrial society. Boston: Beacon Press.

Marcuse, H. (1969). An essay on liberation. Boston: Beacon Press.

Marcuse, H. (1972). Counterrevolution and revolt. Boston: Beacon Press.

Marcuse, H. (2009). Lecture on education, Brooklyn College, 1968. In D. Kellner, T. Lewis, C. Pierce, \& K. Cho (Eds.), Marcuse's challenge to education (pp.33-39). Lanham, Maryland: Rowman \& Littlefield.

Marcuse, H. (2009). Lecture on higher education and politics, Berkeley, 1975. In D. Kellner, T. Lewis, C. Pierce, \& K. Cho (Eds.), Marcuse's challenge to education (pp.39-43). Lanham, Maryland: Rowman \& Littlefield.

Markham, A. (2011). Internet research. In D. Silverman (Ed.), Qualitative Research (3 ${ }^{\text {rd }}$ ed.) (pp.111-127). London: Sage.

Martin, I. \& Shaw, M. (1997). Time for social purpose. Adults Learning, 9(3), 11-13.

Marx, K. (2009). Das kapital. Washington: Regnery. (Original publication date 1867).

McKay, E. \& Vilela, C. (2011). Corporate sector practice informs online workforce training for Australian government agencies: Towards effective educational-learning systems design. Australian Journal of Adult Learning, 51(2), 302-328.

McLaren, P. (1999). A pedagogy of possibility: Reflecting upon Paulo Freire's politics of education. Educational Researcher, March, 49-56.

Merriam, S., Caffarella, R., \& Baumgartner, L. (2007). Learning in adulthood: A comprehensive guide ( ${ }^{\text {rd }}$ ed.). San Francisco, CA: Jossey-Bass.

Mojab, S. (2005). Class and race. New Directions for Adult \& Continuing Education, 106, 73-82.

Moran, M., Seaman, J., \& Tinti-Kane, H. (2011). Teaching, learning, and sharing: How today's higher education faculty use social media. Report by Babson Survey Research Group. Available at http://www.eric.ed.gov.www.msvu.ca:2048/PDFS/ED535130.pdf

Ng, R. (1993). "A woman out of control": Deconstructing sexism and racism in the university. Canadian Journal of Education, $18(3), 189-205$.

Olssen, M. (2006). Understanding the mechanisms of neoliberal control: Lifelong learning, flexibility and knowledge capitalism. International Journal of Lifelong Education, 25(3), 213-230.

Pikalek, A. (2010). Navigating the social media learning curve. Continuing Higher Education Review, 74, 150-160.

Plumb, D. (1999). Adult education in a world "on speed". Studies in Continuing Education, 21(2), 141-161.

Regina, T. (2010). Engaged pedagogy and critical race feminism. Educational Foundations, 24(3-4), 19-26.

Reich, J., Levinson, M., \& Johnston, W. (2011). Using online social networks to foster preservice teachers' membership in a networked community of praxis. Contemporary Issues in Technology and Teacher Education, 11(4), 382-397. 
Reitz, C. (2009). Herbert Marcuse and the humanities: Emancipatory education vs. predatory capitalism. In D. Kellner, T. Lewis, C. Pierce, \& K. Cho (Eds.), Marcuse's challenge to education (pp.229-249). Lanham, Maryland: Rowman \& Littlefield.

Samuels, B. (2011). Facebook, Twitter, YouTube - and democracy. Academe, 97(4), 1-3.

Selman, M. (2011). Canadian adult education: Still a movement? Canadian Journal of University Continuing Education, 37(2), 1-7.

Smith, D. (1987). The everyday world as problematic: A feminist sociology. Boston: Northeastern University Press.

Smith, D. (2006). Institutional ethnography as practice. Lanham, Maryland: Rowman \& Littlefield.

Sowards, S. \& Renegar, V. (2004). The rhetorical functions of consciousness-raising in third wave feminism. Communication Studies, 55(4), 535-552.

St. F.X. Angus L. MacDonald Library Quotes by Rev. Dr. Moses Coady (n.d.). Available at http://stfx.cairnrepo.org/fedora/repository/stfx\%3Axxng-001

Syracuse University Smith (n.d.). Available at http://faculty.maxwell.syr.edu/mdevault/dorothy smith.htm

Taber, N. (2010). Institutional ethnography, autoethnography, and narrative: An argument for incorporating multiple methodologies. Qualitative Research, 10(5), 5-25.

Uggla, B. (2008). Who is the lifelong learner? Globalization, lifelong learning and hermeneutics. Studies in Philosophy and Education, 27, 211-226.

Valdivia, A. (2002). bell hooks: Ethics from the margins. Qualitative Inquiry, 8, 429-447.

van Heertum, R. (2006). Marcuse, Bloch and Freire: Reinvigorating a pedagogy of hope. Policy Futures in Education, 4(1), 4551.

Welton, M. (2006). Intimations of a just learning society: From the United Farmers of Alberta to Henson's Provincial Plan in Nova Scotia. In T. Fenwick, T. Nesbit, \& B. Spencer (Eds.), Contexts of adult education: Canadian perspectives (pp.24-35). Toronto, ON: Thompson. 